\title{
Ordovician metagranitoid from the Anatolide-Tauride Block, northwest Turkey: geodynamic implications
}

\author{
Aral I. Okay, ${ }^{1}$ Muharrem Satır ${ }^{2}$ and Cosmas K. Shang ${ }^{2}$ \\ ${ }^{1}$ Avrasya Yerbilimleri Enstitüsü, İstanbul Teknik Üniversitesi, Ayazağa 80626 Ístanbul, Turkey; ${ }^{2}$ Institut für Geowissenschaften, Üniversität \\ Tübingen, Wilhelmstrasse 56, D-72074 Tübingen, Germany
}

\begin{abstract}
We report a Middle Ordovician metagranitoid from the northern margin of the Anatolide-Tauride Block, the basement of which is generally characterized by voluminous Latest Proterozoic to Early Cambrian granitoids. The Ordovician metagranitoid forms an 400 -m-thick body in the marbles and micaschists of the Tavşanlı Zone. The whole sequence was metamorphosed in the blueschist facies during the Late Cretaceous (c. $80 \mathrm{Ma}$ ). Zircons from the metagranitoid give a Middle Ordovician $\mathrm{Pb}-\mathrm{Pb}$ evaporation age of $467.0 \pm 4.5 \mathrm{Ma}$ interpreted as the age of crystallization of the parent granitic magma. The micaschists underlying the metagranitoid yield Cambro-Ordovician
\end{abstract}

(530-450 Ma) and Carboniferous (c. $310 \mathrm{Ma}$ ) detrital zircon ages indicating that the granitoid is a pre- or syn-metamorphic tectonic slice. The Ordovician metagranitoid represents a remnant of the crystalline basement of the Anatolide-Tauride Block and provides evidence for Ordovician magmatism at the northern margin of Gondwana. Prismatic Carboniferous detrital zircons in the micaschists indicate that during the Triassic, the northern margin of the Anatolide-Tauride Block was close to Variscan terranes.

Terra Nova, 20, 280-288, 2008

\section{Introduction}

Pan-African granitoids with ages of 600-500 Ma crop out over large areas in Arabia and northern Africa (e.g. Veevers, 2004). The Anatolide-Tauride Block of southern Turkey was attached to Africa during the Palaeozoic (e.g. Şengör and Yılmaz, 1981) and its basement, as exposed in the Menderes Massif, also comprises widespread granitoid plutons with ages of 570-520 Ma (e.g. Satir and Friedrichsen, 1986; Kröner and Şengör, 1990; Hetzel and Reischmann, 1996; Loos and Reischmann, 1999; Gürsü and Göncüoğlu, 2006). Here we report a Middle Ordovican (c. $467 \mathrm{Ma}$ ) granitoid from the northern margin of the Anatolide-Tauride Block and discuss its tectonic significance. The Ordovician granitoid reported here is the first of its age from the northern margin of Gondwana in the Eastern Mediterranean realm.

\section{Geological setting}

The Ordovician metagranitoid occurs in the Tavşanlı Zone, a blueschist-

Correspondence: Aral. I. Okay, Avrasya Yerbilimleri Enstitüsü, İstanbul Teknik Üniversitesi, Ayazağa 80626 İstanbul, Turkey. Tel.: (90) 21228562 08; fax: (90) 21228562 10; e-mail: okay@itu.edu.tr facies metamorphic belt, $\sim 250 \mathrm{~km}$ long and $\sim 50 \mathrm{~km}$ wide, immediately south of the main Tethyan IzmirAnkara suture (Fig. 1, Okay, 2002; Droop et al., 2005; Davis and Whitney, 2006). The blueschist sequence in the Tavşanlı Zone consists of basal micaschists, overlain by marbles, which are in turn overlain by a series of metabasite, metachert and phyllite. The blueschists represent a segment of the subducted and subsequently exhumed passive continental margin of the Anatolide-Tauride Block (Okay, 1984). Phengite Rb-Sr and Ar-Ar data from the blueschists indicate a Late Cretaceous $(80 \pm 5 \mathrm{Ma})$ age for the HP/LT metamorphism (Sherlock et al., 1999). The blueschist sequence is tectonically overlain by a Cretaceous oceanic accretionary complex of basalt, radiolarian chert and pelagic shale. Large tectonic slabs of ophiolite, predominantly peridotite, lie over the coherent blueschists or over the accretionary complex (Fig. 1).

The Kapanca metagranitoid crops out in the western part of the Tavşanlı Zone southeast of the town of Orhaneli (Fig. 2). In this region, the blueschists are represented predominantly by micaschist and marble (Lisenbee, 1971; Okay and Kelley, 1994; Okay, 2002). The micaschists form grey, finely banded, hard, medium-grained rocks, at least $\sim 800 \mathrm{~m}$ in thickness, representing metamorphosed pelites and sandstones. The base of the micaschist sequence is not exposed; the schists are overlain by white marbles, over $400 \mathrm{~m}$ in thickness. Marble and micaschist bands, several metres thick, are intercalated in the transition zone between the schist and marble series.

The micaschists show a strong ductile deformation with the development of penetrative foliation and mineral lineation. Isoclinal folds are present from the scale of thin section to 200$300 \mathrm{~m}$ with generally east-west trending fold axes, parallel to the stretching lineation (Lisenbee, 1971). Thin marble layers in the schists are stretched out in the fold limbs and are seldom continuous for more than a few hundred metres.

The Kapanca metagranitoid is preserved in the core of an open synform south of Orhaneli, and occupies an area of $1.5 \mathrm{~km}$ by $1 \mathrm{~km}$ with a thickness of $\sim 400 \mathrm{~m}$ (Fig. 3). It is underlain either by marble or, where the marble pinches out, by the micaschists. The Kapanca metagranitoid is massive, extremely hard, white to pale grey with medium to coarse grain size and a homogeneous texture. Compared to the surrounding micaschists, it has undergone a small amount of strain; the granitic texture, with equant quartz and jadeite grains or grain aggregates is recognizable in the massive outcrops (Fig. 4). A finegrained, dark bluish grey metabasite 


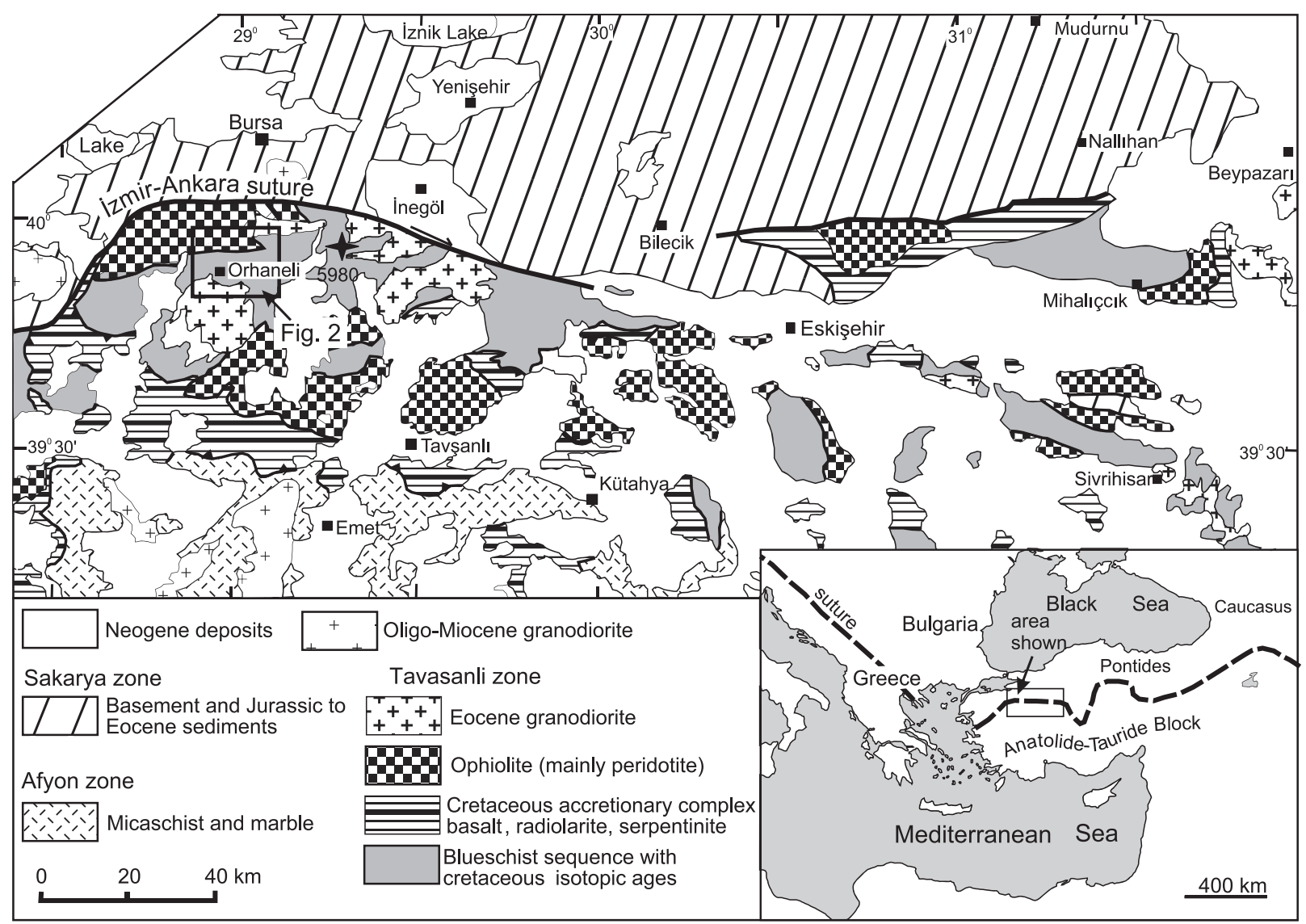

Fig. 1 Tectonic map of northwest Turkey showing the regional distribution of the blueschists (modified from Okay, 2002).

body, $\sim 100 \mathrm{~m}$ across, occurs in the core of the metagranitoid. It is cut by metaaplitic and metapegmatitic veins, and probably represents a co-magmatic intrusion or a large xenolith.

During syn-metamorphic stretching the Kapanca metagranitoid behaved as a rigid body, with marble forming pinch-and-swell structures and boudins, and the micaschist deforming plastically. These differences in rheology led to the juxtaposition of the Kapanca metagranitoid both with the marble and with the micaschists (Fig. 3). However, there is no evidence for post-metamorphic shearing along the contacts. The common highpressure mineral assemblages in the Kapanca metagranitoid and the surrounding micaschists indicate that they have undergone a common high-pressure metamorphism.

\section{Geochemistry and petrology}

The Kapanca metagranitoid shows a range of $\mathrm{SiO}_{2}(71-62$ wt.\%) and low $\mathrm{MgO} \quad(1.0-1.3 \quad$ wt. \%) contents and has a meta-aluminous to weakly peraluminous composition [molar $\mathrm{Al}_{2} \mathrm{O}_{3} /\left(\mathrm{CaO}+\mathrm{K}_{2} \mathrm{O}+\mathrm{Na}_{2} \mathrm{O}\right)=0.9-$ 1.1] (Table 1). Low $\mathrm{Cr}$ and $\mathrm{Ni}$ contents together with low $\mathrm{Mg}$ number [molar $\mathrm{MgO} /\left(\mathrm{MgO}+\mathrm{FeO}^{\text {total }}\right)=$ $0.3-0.5]$ suggest a crustal derivation of the granitic magma. A peculiar feature of the metagranitoid is the high $\mathrm{Na}_{2} \mathrm{O}$ (5-6 wt.\%) and very low $\mathrm{K}_{2} \mathrm{O}(<1.0$ wt. $\%)$ contents leading to $\mathrm{K}_{2} \mathrm{O} / \mathrm{Na}_{2} \mathrm{O}$ ratios of $<0.2$. The surrounding metapelitic micaschists are also highly sodic (Okay and Kelley, 1994) suggesting that the enrichment in $\mathrm{Na}_{2} \mathrm{O}$ may be a secondary feature arising from interaction with seawater in a subduction zone, a phenomenon analogous to spilitization. On the basis of molar $\mathrm{Al}_{2} \mathrm{O}_{3}, \mathrm{CaO}, \mathrm{Na}_{2} \mathrm{O}$ and $\mathrm{K}_{2} \mathrm{O}$ contents, the Kapanca metagranitoid plots in the field of continental-arc granitoids in the plate-tectonic discrimination diagram of Maniar and Piccoli (1989).

The mineral assemblage in the Kapanca metagranitoid is quartz + jadeite + chloritoid + lawsonite + glaucophane + phengite \pm albite \pm chlorite \pm sericite. Quartz and jadeite constitute over half of the mode. The four minerals, jadeite, chloritoid, sodic amphibole and lawsonite, occur in close proximity and are inferred to be in textural equilibrium. Chlorite, albite and sericite are late minerals. Similar mineral assemblages exist in the surrounding micaschists and indicate peak pressure-temperature conditions for the blueschist-facies metamorphism of $24 \pm 3 \mathrm{kbar}$ and $430 \pm$ $30{ }^{\circ} \mathrm{C}$ (Okay, 2002).

\section{Geochronology}

Zircons from two samples of Kapanca metagranitoid were dated using the single-grain-stepwise $\mathrm{Pb}-\mathrm{Pb}$ evaporation method developed by Kober (1986, 1987). The details of the dating procedure are given in Okay et al. (2006). The dated zircons, eight grains from each sample, were reddish, $0.063-0.125$ or $0.125-0.200 \mathrm{~mm}$ long, medium to thick and prismatic. The ages obtained are $467 \pm 9$ for sample 


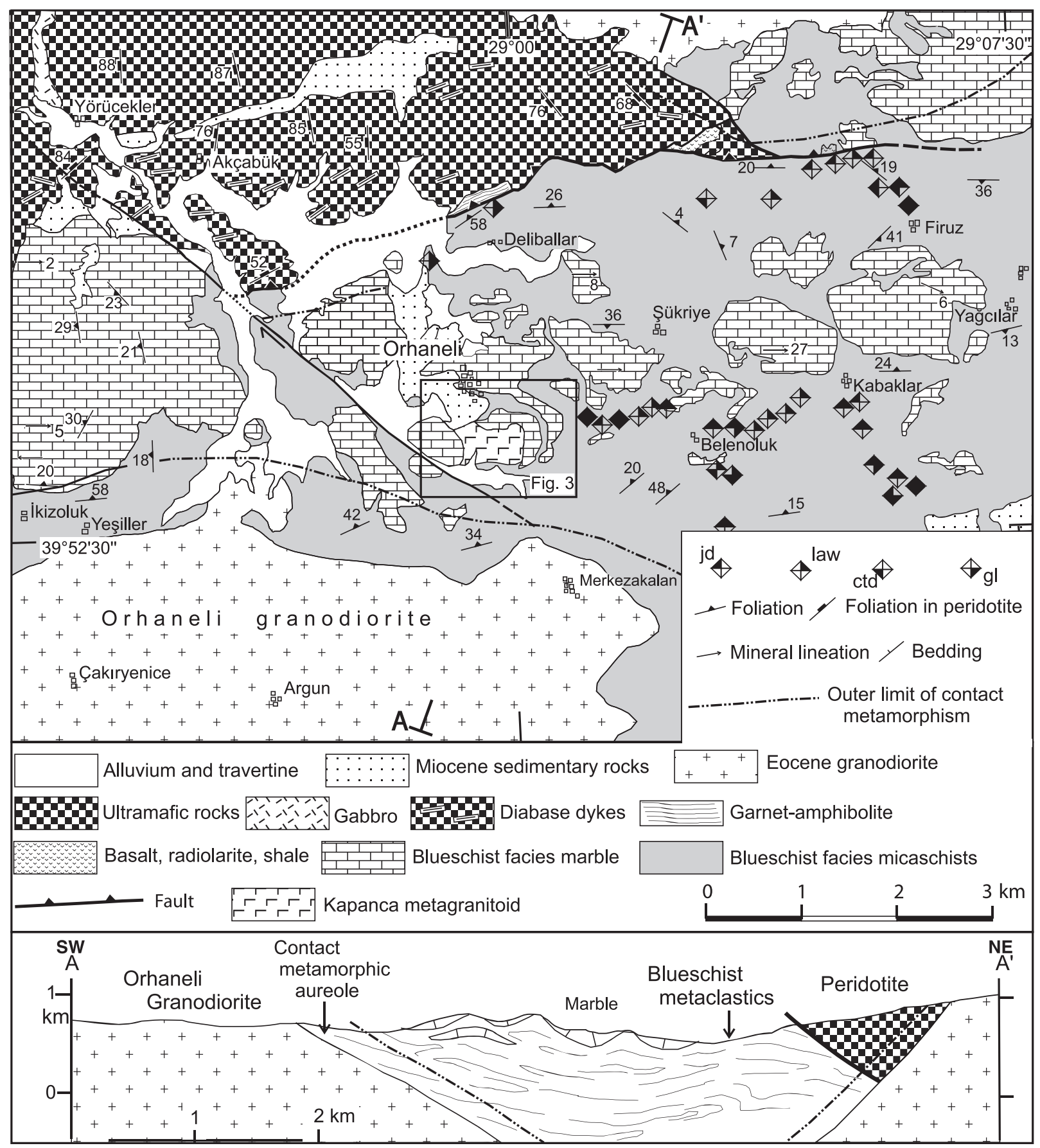

Fig. 2 Geological map and cross-section of the Orhaneli region (modified from Lisenbee, 1971; Okay, 2002) showing the distribution of the high-pressure mineral assemblages. For location see Fig. 1.

6818A and 467.0 \pm 4.8 Ma for sample 6818B (Fig. 5a, Table 2) and yield a mean of $467.0 \pm 4.5 \mathrm{Ma}(95 \%$ confidence level). All 16 zircon grains from the two samples gave similar ages indicating that they reflect the crystallization age of the parent granitic magma during the Middle Ordovician. The temperatures of the
Cretaceous high-pressure metamorphism were too low $\left(<450{ }^{\circ} \mathrm{C}\right)$ to reset the zircon ages.

We have also dated detrital zircons from an adjacent micaschist to establish whether the Kapanca metagranitoid is a small intrusion or is allochthonous. The dated micaschist (6819) was collected $1.5 \mathrm{~km}$ northwest of the Kapanca metagranitoid and lies structurally underneath the metagranitoid (Fig. 3). It consists of quartz + jadeite + phengite + chlorite + albite. Seventeen zircon grains, all in the range of $0.125-0.200 \mathrm{~mm}$, from the micaschist produced two prominent age peaks (Fig. 5b, Table 2). A broad peak of Cambrian 


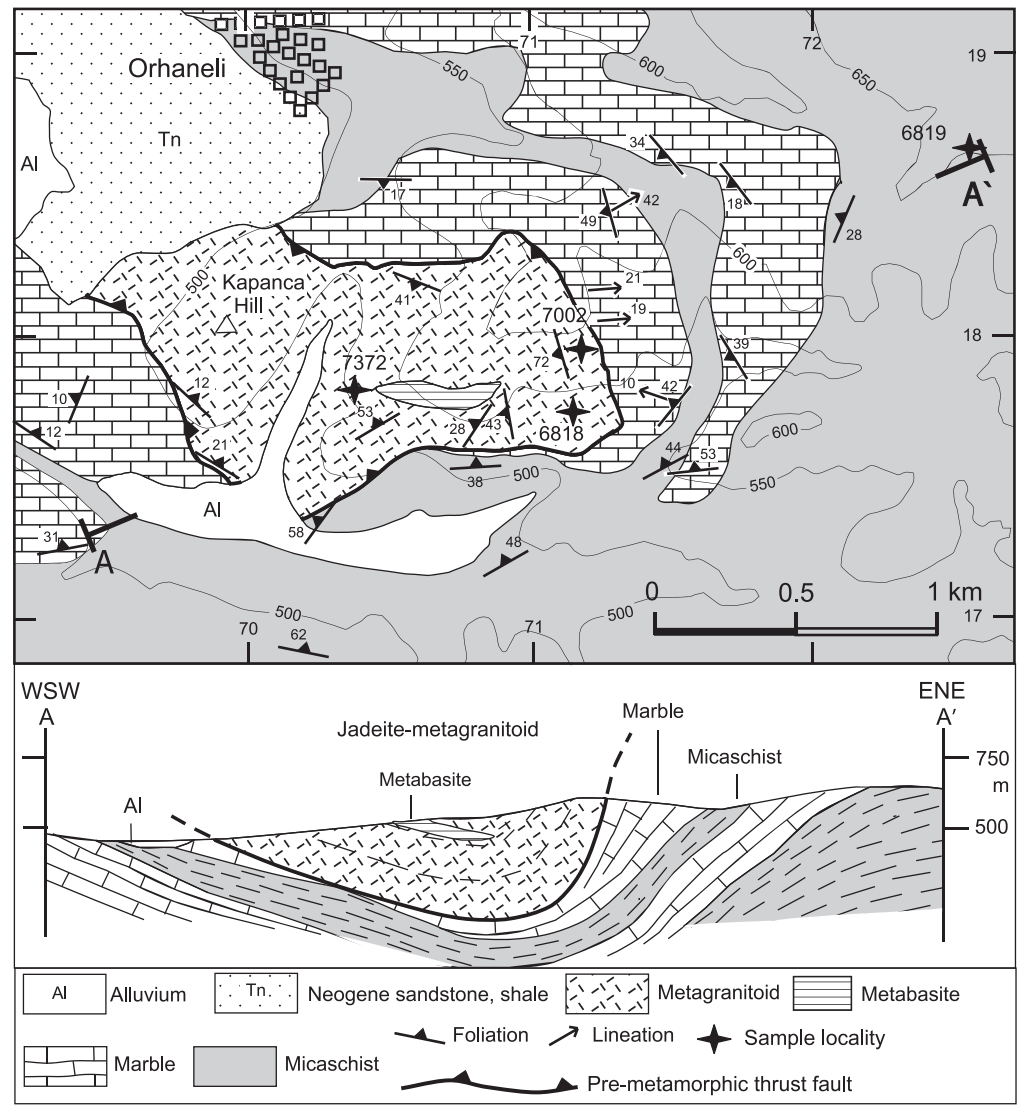

Fig. 3 Geological map and cross-section of the jadeite-metagranitoid with sample localities. The geographic coordinates are in UTM and the contours are at every $50 \mathrm{~m}$.

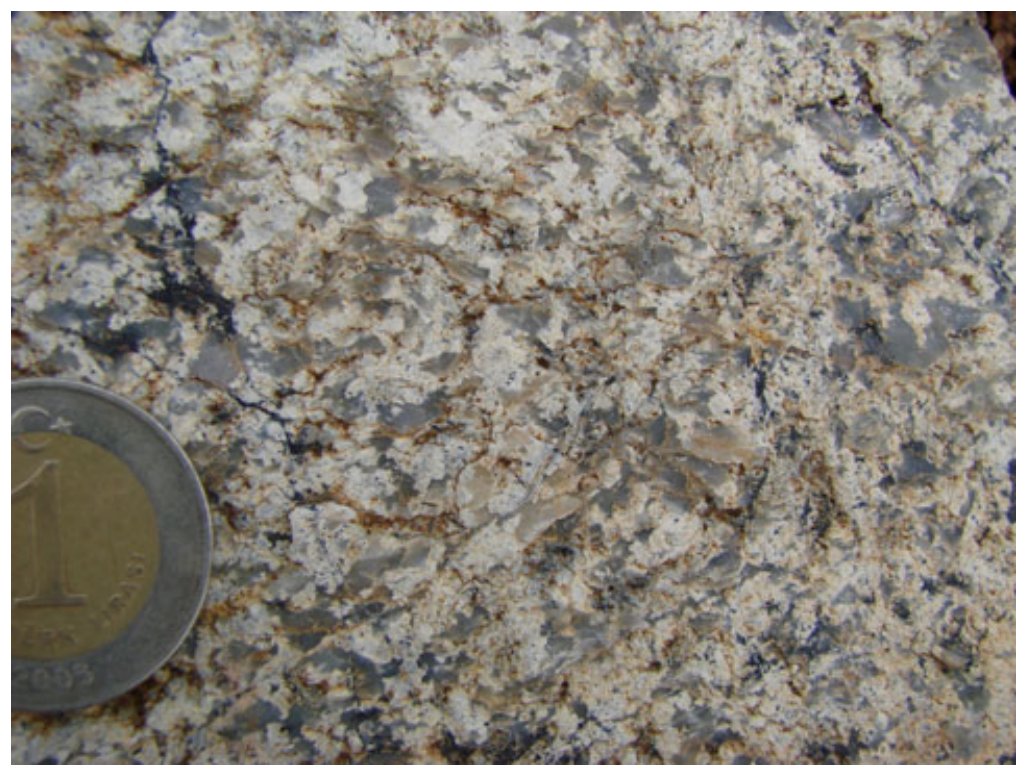

Fig. 4 Field photo of the jadeite-metagranitoid. The white grains are jadeite and the glassy greyish areas consist of quartz aggregates. Note the lack of strain. The coin is $2 \mathrm{~cm}$ across. and Ordovician ages between 450 and $530 \mathrm{Ma}$, and a narrow Late Carboniferous peak at $c .310 \mathrm{Ma}$. In addition, one rounded and colourless zircon grain gave a late Archean age of $2563 \mathrm{Ma}$. Carboniferous zircons were prismatic and reddish, whereas Cambro-Ordovician zircons were rounded and colourless.

The Carboniferous zircon ages from the micaschists indicate that the Kapanca metagranitoid represents either a tectonic sliver from the basement or an olistolith. We favour the former as no metaconglomerates that could be interpreted as debris flows were observed in the micaschist and marble sequence.

We have also dated another micaschist sample, which lies structurally and stratigraphically lower down in the schist series. The sample locality lies $28 \mathrm{~km}$ east of Orhaneli in the vicinity of one of the Eocene granodiorites (Fig. 1). The micaschists in this region are overprinted by an Eocene dynamothermal metamorphism that resulted in the loss of the highpressure mineral assemblages (Okay and Satır, 2006). Sample 5980 contains quartz, albite, muscovite, biotite and chlorite. Three colourless zircon grains with dark inclusions $(0.063-$ $0.125 \mathrm{~mm}$, one rounded, one shortprismatic and one long-prismatic) from the biotite-micaschist yielded Proterozoic ages between 1915 and $694 \mathrm{Ma}$, whereas a fourth grain gave a Carboniferous age, similar to that obtained from the jadeite-micaschist.

The zircon age data indicate that the depositional age of the micaschists is Late Carboniferous or younger. In the Anatolide-Tauride Block, a clastic dominated succession of Palaeozoic to Mid-Triassic age passes up into a Late Triassic to Cretaceous carbonate sequence (e.g. Gutnic et al., 1979). Comparison with this stratigraphy suggests an Early to Mid Triassic depositional age for the micaschists.

\section{Discussion}

The Kapanca metagranitoid forms a pre- to syn-metamorphic tectonic slice immediately south of the İzmirAnkara suture (Fig. 1), which might suggest a tectonic derivation from the Pontides. However, the deformation and metamorphism in the Tavşanlı Zone pre-dates the Palaeocene - Early 
Table 1 Whole-rock major and trace element data from the jadeite-metagranitoid.

\begin{tabular}{lcc}
\hline Sample & 7002 & 7372 \\
\hline $\mathrm{SiO}_{2}$ & 70.70 & 61.56 \\
$\mathrm{TiO}_{2}$ & 0.20 & 0.73 \\
$\mathrm{Al}_{2} \mathrm{O}_{3}$ & 15.21 & 17.20 \\
$\mathrm{Fe}_{2} \mathrm{O}_{3}$ & 2.44 & 5.34 \\
$\mathrm{MgO}$ & 1.04 & 1.31 \\
$\mathrm{MnO}$ & 0.04 & 0.10 \\
$\mathrm{CaO}$ & 2.71 & 4.59 \\
$\mathrm{Na}_{2} \mathrm{O}$ & 5.09 & 6.13 \\
$\mathrm{~K} \mathrm{O}$ & 0.91 & 0.02 \\
$\mathrm{P}_{2} \mathrm{O}_{5}$ & 0.03 & 0.19 \\
$\mathrm{LOI}$ & 2.04 & 3.43 \\
$\mathrm{Ba}$ & 393 & 61 \\
$\mathrm{Co}$ & 54 & 6 \\
$\mathrm{Cr}$ & 0 & 10 \\
$\mathrm{Ni}$ & 41 & 53 \\
$\mathrm{Rb}$ & 24 & 2 \\
$\mathrm{Sr}$ & 170 & 227 \\
$\mathrm{~V}$ & 37 & 42 \\
$\mathrm{Y}$ & 0 & 21 \\
$\mathrm{Zn}$ & 0 & 29 \\
$\mathrm{Zr}$ & 114 & 192 \\
$\mathrm{Nd}$ & 7 & 2.7 \\
$\mathrm{Sm}$ & 2.1 & 14.66 \\
$\mathrm{Total}$ & 100.48 & \\
\hline $\mathrm{OO}$ & &
\end{tabular}

LOI, loss on ignition determined externally at $1050{ }^{\circ} \mathrm{C}$.

0 means below detection limit.

Eocene collision with the Pontides and is related to the Cretaceous subduction of the Anatolide-Tauride Block at a mid-oceanic trench (e.g. Okay and Tüysüz, 1999). Hence, the Kapanca metagranitoid cannot be an exotic thrust sheet from the Pontides, but represents a fragment from the basement of the Anatolide-Tauride Block.

Palaeogeographic reconstructions place the Anatolide-Tauride Block at the northern margin of Gondwana between Egypt and Cyprus during the Palaeozoic with separation from Gondwana occurring in the Triassic (Fig. 6, e.g. Şengör and Y1lmaz, 1981; Stampfli and Borel, 2002; Garfunkel, 2004). The recent recognition of Late Ordovician glacial deposits in the Anatolide-Tauride Block and in the Arabian Platform of southeast Anatolia also place constraints on the Ordovician palaeogeography of the Eastern Mediterranean region (Monod et al., 2003). However, it is uncertain what lay to the north of the Anatolide-Tauride Block during the Ordovician. Although the Pontides are also Gondwana derived, they do
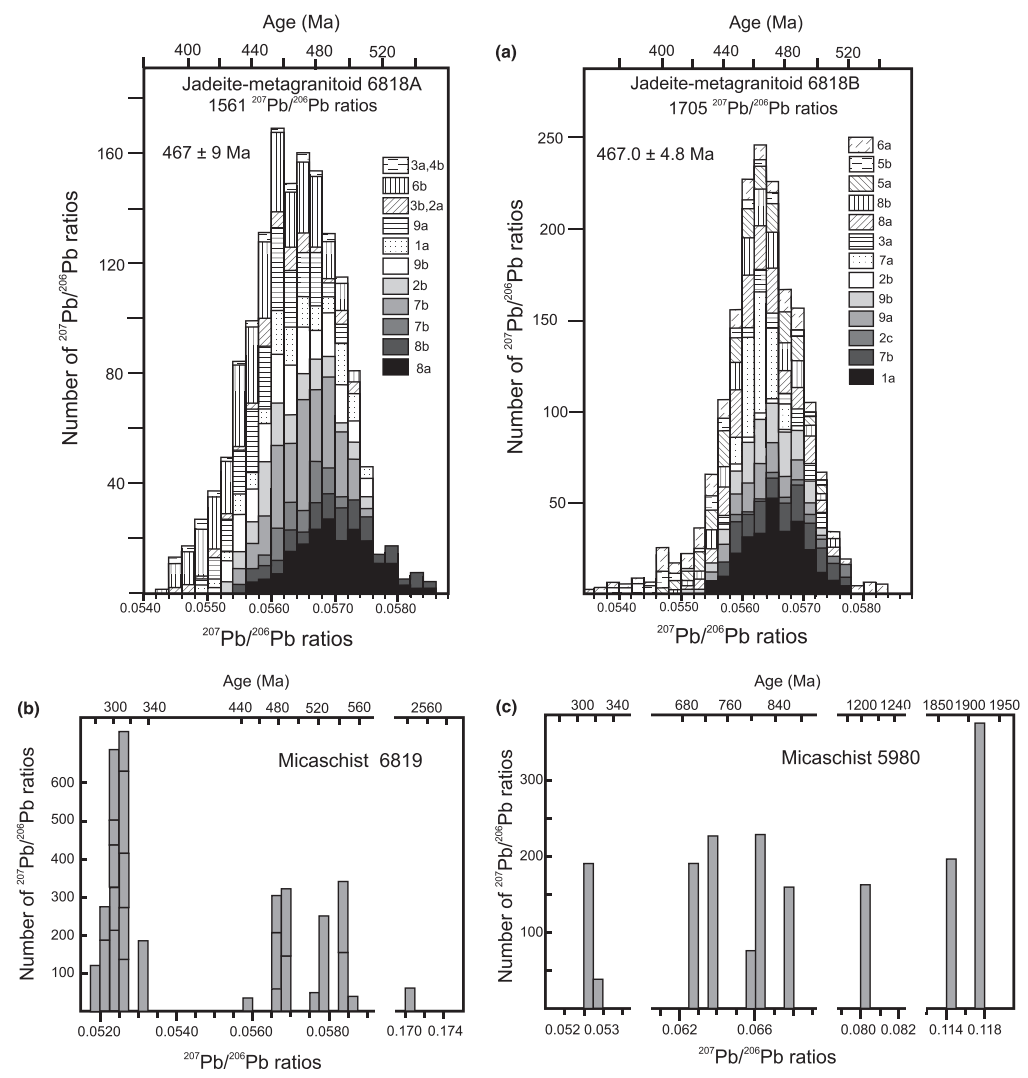

Fig. 5 Histograms showing the distribution of radiogenic lead isotope ratios derived from the evaporation of: (a) 16 zircon grains from the jadeite-metagranitoid samples $6818 \mathrm{~A}$ and $6818 \mathrm{~B}$, (b) 18 zircon grains from the jadeite-micaschist sample 6819 , (c) five grains from the biotite-micaschist sample 5980.

not constitute a conjugate margin with the Anatolide-Tauride Block (e.g. Stampfli, 2000; Okay et al., 2006). Therefore, their basement, which includes minor Ordovician (c. $460 \mathrm{Ma}$ ) granitoids (Okay et al., 2008) does not represent the northern extension of the Anatolide-Tauride basement.

No Ordovician magmatic rocks are reported from the Palaeozoic sequences of the Anatolide-Tauride Block. In the Tauride Palaeozoic series, Lower Ordovician shales and siltstones (the Seydişehir Formation) are generally unconformably overlain by Upper Ordovician deposits with glacial conglomerates and sandstones (e.g. Monod et al., 2003). Ordovician magmatism is also not known from the Arabian platform. In contrast, Ordovician magmatic rocks are described from peri-Gondwana terranes, such as the Massif Central (e.g. Roger et al., 2004), the Pyrenees
(Deloule et al., 2002), the Saxothuringian (Schätz et al., 2002) and the Alps (von Raumer et al., 2002). The tectonic setting of the Ordovician magmatism in these peri-Gondwana terranes possibly includes rift, magmatic arc as well as late- to post-collisional settings (von Raumer et al., 2003; Mattauer, 2004). In the plate-tectonic discrimination diagrams based on major elements the Kapanca metagranitoid plots in the field of continental-arc granitoids. However, these diagrams make use of alkali elements, which can be highly mobile during metamorphism (e.g. Pearce, 1976; Allen et al., 1985). The Ordovician sequences in the AnatolideTauride Block do not comprise any volcanic rocks or volcanic-derived detritus (e.g. Gutnic et al., 1979; Monod et al., 2003), and this is not compatible with the presence of a major magmatic arc on the northern margin of the Anatolide-Tauride Block. On the other hand, most 
Table 2 Single grain ${ }^{207} \mathrm{~Pb} /{ }^{206} \mathrm{~Pb}$ zircon evaporation data.

\begin{tabular}{|c|c|c|c|c|c|c|}
\hline \multicolumn{2}{|c|}{ Zircon grain characteristics } & $\begin{array}{l}\text { Evap. } \\
\text { temp. }\left({ }^{\circ} \mathrm{C}\right)\end{array}$ & No. scans & $\begin{array}{l}\text { Mean value } \\
\text { of }{ }^{207} \mathrm{~Pb} /{ }^{206} \mathrm{~Pb} \\
\text { ratios }\end{array}$ & $\begin{array}{l}{ }^{207} \mathrm{~Pb} /{ }^{206} \mathrm{~Pb} \\
\text { age (Ma) }\end{array}$ & $2 \sigma$ error \\
\hline 1 & $125-200 \mu \mathrm{m}$, thick, prismatic, reddish & 1380 & 112 & $0.056402 \pm 127$ & 468.3 & 5.5 \\
\hline \multirow[t]{2}{*}{2} & $125-200 \mu \mathrm{m}$, very thick, prismatic, red & 1380 & 36 & $0.055972 \pm 233$ & 451.3 & 9.6 \\
\hline & & 1420 & 101 & $0.056293 \pm 113$ & 464.0 & 5.0 \\
\hline 4 & 63-125 $\mu \mathrm{m}$, medium long, prismatic, reddish & 1400 & 40 & $0.055824 \pm 283$ & 445.4 & 11.6 \\
\hline 6 & 63-125 $\mu \mathrm{m}$, medium long, prismatic, reddish & 1400 & 271 & $0.055821 \pm 085$ & 445.3 & 4.1 \\
\hline \multirow[t]{2}{*}{7} & $125-200 \mu \mathrm{m}$, big, short, prismat,c, reddish & 1380 & 225 & $0.056544 \pm 063$ & 473.8 & 3.4 \\
\hline & & 1420 & 63 & $0.056509 \pm 086$ & 472.4 & 4.1 \\
\hline \multirow[t]{2}{*}{8} & $125-200 \mu \mathrm{m}$, long prismatic, reddish & 1380 & 189 & $0.056993 \pm 085$ & 491.3 & 4.0 \\
\hline & & 1420 & 99 & $0.056957 \pm 151$ & 489.9 & 6.3 \\
\hline 1 & 125-200 $\mu \mathrm{m}$, thick, prismatic, red & 1380 & 274 & $0.056543 \pm 057$ & 473.8 & 3.2 \\
\hline \multirow[t]{2}{*}{2} & 125-200 $\mu \mathrm{m}$, big, long, prismatic, red & 1400 & 34 & $0.056782 \pm 207$ & 483.1 & 8.4 \\
\hline & & 1420 & 27 & $0.056289 \pm 206$ & 463.8 & 8.5 \\
\hline 3 & $125-200 \mu \mathrm{m}$, medium long, prismatic, reddish & 1400 & 68 & $0.056517 \pm 138$ & 472.8 & 5.9 \\
\hline \multirow[t]{2}{*}{5} & $125-200 \mu \mathrm{m}$, medium long, prismatic, reddish & 1400 & 150 & $0.056077 \pm 104$ & 455.5 & 4.7 \\
\hline & & 1420 & 79 & $0.055574 \pm 226$ & 434.4 & 9.4 \\
\hline 6 & $125-200 \mu \mathrm{m}$, medium long, prismatic, reddish & 1400 & 164 & $0.055998 \pm 183$ & 452.3 & 7.7 \\
\hline \multirow[t]{2}{*}{7} & $125-200 \mu \mathrm{m}$, long, prismatic, reddish & 1390 & 187 & $0.056285 \pm 029$ & 463.7 & 2.6 \\
\hline & & 1420 & 148 & $0.056647 \pm 092$ & 477.8 & 4.3 \\
\hline \multirow[t]{2}{*}{8} & 125-200 $\mu \mathrm{m}$, thick, prismatic, red & 1390 & 188 & $0.056330 \pm 081$ & 465.4 & 3.9 \\
\hline & & 1420 & 133 & $0.056267 \pm 082$ & 463.0 & 4.0 \\
\hline 9 & $125-200 \mu \mathrm{m}$, thick, prismatic, red & 1390 & 106 & $0.056339 \pm 086$ & 465.8 & 4.1 \\
\hline \multirow[t]{3}{*}{5} & 125-200 $\mu \mathrm{m}$, big, prismatic, red & 1380 & 211 & $0.052482 \pm 051$ & 306.5 & 3.2 \\
\hline & & 1400 & 112 & $0.052382 \pm 043$ & 302.2 & 3.0 \\
\hline & & 1420 & 136 & $0.052570 \pm 093$ & 310.3 & 4.7 \\
\hline 6 & 125-200 $\mu \mathrm{m}$, medium, prismatic, red & 1380 & 185 & $0.052061 \pm 067$ & 288.1 & 3.8 \\
\hline & & 1400 & 149 & $0.052588 \pm 120$ & 311.1 & 5.7 \\
\hline & & 1420 & 88 & $0.052100 \pm 157$ & 289.8 & 7.3 \\
\hline 7 & $125-200 \mu \mathrm{m}$, medium, prismatic, reddish & 1380 & 121 & $0.051946 \pm 152$ & 283.1 & 6.8 \\
\hline & & 1420 & 142 & $0.052569 \pm 093$ & 310.3 & 4.7 \\
\hline 8 & $125-200 \mu \mathrm{m}$, medium, prismatic, reddish & 1380 & 215 & $0.052526 \pm 074$ & 308.4 & 4.0 \\
\hline & & 1400 & 110 & $0.052493 \pm 043$ & 307.0 & 3.0 \\
\hline & & 1420 & 104 & $0.052583 \pm 065$ & 310.9 & 3.7 \\
\hline 9 & $125-200 \mu \mathrm{m}$, medium, rounded, colourless & 1380 & 60 & $0.170615 \pm 288$ & 2563.8 & 3.3 \\
\hline 10 & 125-200 $\mu \mathrm{m}$, medium, flattened, reddish & 1380 & 65 & $0.052349 \pm 146$ & 300.7 & 6.8 \\
\hline 11 & $125-200 \mu \mathrm{m}$, thick, rounded, colourless & 1380 & 249 & $0.057899 \pm 108$ & 526.0 & 4.7 \\
\hline & & 1420 & 38 & $0.058662 \pm 089$ & 554.6 & 4.1 \\
\hline 12 & $125-200 \mu \mathrm{m}$, thick, prismatic, reddish & 1420 & 185 & $0.052512 \pm 044$ & 307.8 & 3.0 \\
\hline 13 & $125-200 \mu \mathrm{m}$, medium, rounded, light yellow & 1420 & 185 & $0.053103 \pm 194$ & 333.2 & 8.7 \\
\hline 14 & $125-200 \mu \mathrm{m}$, medium, rounded, light yellow & 1420 & 144 & $0.056770 \pm 151$ & 482.7 & 6.4 \\
\hline 16 & $125-200 \mu \mathrm{m}$, medium, rounded, light yellow & 1420 & 176 & $0.056751 \pm 150$ & 481.9 & 6.4 \\
\hline 17 & $125-200 \mu \mathrm{m}$, medium, rounded, light yellow & 1420 & 186 & $0.058303 \pm 065$ & 541.4 & 3.4 \\
\hline 18 & $125-200 \mu \mathrm{m}$, medium, rounded, light yellow & 1420 & 97 & $0.056684 \pm 151$ & 479.3 & 5.0 \\
\hline Bio & -micaschist 5980 & & & & & \\
\hline 1 & 63-125 $\mu \mathrm{m}$, medium, short, rounded, colourless, dark inclusions & 1380 & 76 & $0.065851 \pm 143$ & 801.7 & 4.9 \\
\hline
\end{tabular}


Table 2 Continued.

\begin{tabular}{|c|c|c|c|c|c|c|}
\hline \multicolumn{2}{|c|}{ Zircon grain characteristics } & $\begin{array}{l}\text { Evap. } \\
\text { temp. }\left({ }^{\circ} \mathrm{C}\right) \\
1390\end{array}$ & $\begin{array}{l}\text { No. scans } \\
196\end{array}$ & $\begin{array}{l}\begin{array}{l}\text { Mean value } \\
\text { of }{ }^{207} \mathrm{~Pb} /{ }^{206} \mathrm{~Pb} \\
\text { ratios }\end{array} \\
0.114600 \pm 086\end{array}$ & $\begin{array}{l}{ }^{207} \mathrm{~Pb} /{ }^{206} \mathrm{~Pb} \\
\text { age }(\mathrm{Ma}) \\
1873.7\end{array}$ & $\begin{array}{l}2 \sigma \text { error } \\
2.4\end{array}$ \\
\hline & & 1420 & 374 & $0.117264 \pm 046$ & 1915.0 & 2.1 \\
\hline \multirow[t]{2}{*}{4} & 63-125 $\mu \mathrm{m}$, medium, rounded, colourless, dark inclusion & 1390 & 226 & $0.063951 \pm 057$ & 740.1 & 2.8 \\
\hline & & 1420 & 159 & $0.067969 \pm 080$ & 868.6 & 3.2 \\
\hline & & 1430 & 38 & $0.052840 \pm 020$ & 322.0 & 2.5 \\
\hline
\end{tabular}

All age errors are 2 sigma plus assumed error of $0.1 \%$ which includes potential bias caused by mass fractionation of $\mathrm{Pb}$ isotopes and uncertainty in linearity of the multiplier signal. See error calculation formula below.

The age error of each temperature step was calculated according to the formula:

The number of ${ }^{207} \mathrm{~Pb} /{ }^{206} \mathrm{~Pb}$ isotope ratio scans $(\mathrm{n})$;

The 2 sigma $(2 \sigma)$ standard error of the Gausian distribution function;

$\Delta f$ an assumed error of $0.1 \%$ which includes potential bias caused by mass fractionation of $\mathrm{Pb}$ isotopes and uncertainty in linearity of the multiplier signal $\Delta$ age $=\sqrt{\left(\left(\frac{2 \sigma}{\sqrt{n}}\right)^{2}+\Delta f^{2}\right)}$.

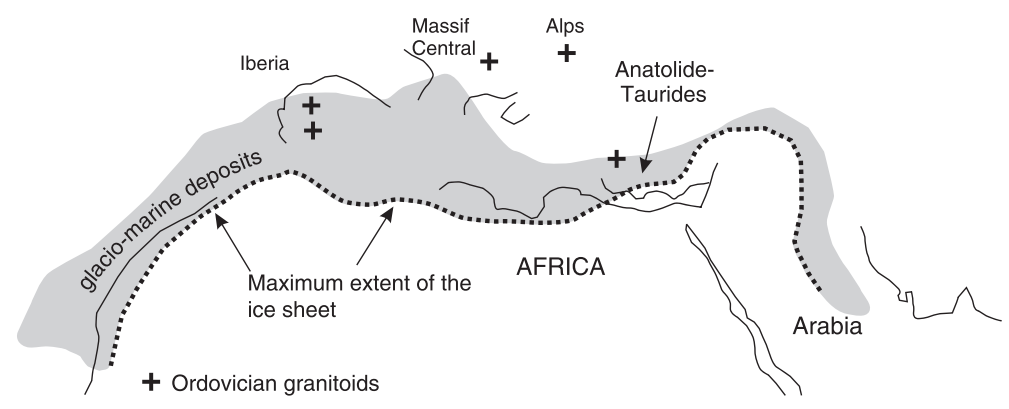

Fig. 6 Distribution of Ordovician granitoids (von Raumer et al., 2002) and the glacial deposits (Monod et al., 2003) in the Eastern Mediterranean realm.

palaeogeographic reconstructions show Ordovician rifting of a continental sliver, corresponding to the eastern extension of Avalonia, from the northern margin of the Anatolide-Tauride Block (e.g. Stampfli, 2000; Cocks and Torsvik, 2002). Based on subsidence analysis from the Welsh basin, the rifting of Avalonia from Gondwana is considered to have occurred between 480 and $462 \mathrm{Ma}$ (Prigmore et al., 1997), compatible with the $467.0 \pm$ 4.5 Ma age of the Kapanca granitoid. Many of the peri-Gondwana terranes in western and central Europe comprise Cambro-Ordovician orogenic units including ophiolites and volcanic rocks (e.g. von Raumer et al., 2002). Absence of such sequences in the AnatolideTauride Block indicate that it lay closer to the stable interior of Gondwana during the Early Palaeozoic, implying a rift-related origin for the Kapanca metagranitoid.
Although most of north-east Africa is characterized by Pan-African crystalline rocks (500-900 Ma, e.g. Kröner et al., 1994), detrital zircons of this age range are rare in the blueschist micaschists, which are dominated by Carboniferous zircons; the prismatic detrital Carboniferous zircons indicate a nearby magmatic source. As Carboniferous intrusives are not known from the AnatolideTauride Block, the source must have lain farther north or northwest possibly in the Strandja and Rhodope massifs in the Balkans, where Carboniferous and Early Permian granitoids with ages of $315-285 \mathrm{Ma}$ are widespread (Wawrzenitz and Krohe, 1998; Okay et al., 2001; Carrigan et al., 2005, 2006). This is compatible with palaeogeographic reconstructions, which show a westward termination of Palaeo-tethys in the vicinity of Turkey resulting in the Variscan belt being positioned close to the Anatolide-Tauride block during the Triassic (e.g. Stampfli, 2000; Matte, 2001; Zanchi et al., 2003; Okay et al., 2006).

\section{Conclusions}

The Middle Ordovician Kapanca metagranitoid occurs within the micaschists and marbles of the Tavşanlı Zone in northwest Turkey. It shares a common metamorphic and structural history with the host rocks, all having undergone a Late Cretaceous high pressure metamorphism. Field relations and zircon age data from the underlying micaschists show that the Kapanca metagranitoid is not an intrusion but rather a pre- or synmetamorphic tectonic sliver from the basement. The major-element geochemistry of the Kapanca granitoid is compatible with a continental-arc tectonic setting. However, the absence of volcanic rocks or volcanic-derived detritus in the Ordovician sequences of the Anatolide-Tauride Block implies a rift-related setting possibly related to rifting of terranes that lay north of the Anatolide-Tauride Block.

The presence of prismatic detrital zircons of Carboniferous age in the micaschists with a Triassic depositional age shows that the northern margin of the Anatolide-Tauride Block was close to the Variscan orogen during the Triassic. 


\section{Acknowledgements}

This study was completed during the tenure of a Fulbright fellowship in UCSB to the senior author. The fieldwork in the Orhaneli region was supported by the TÜBITTAK grant YDABÇAG 419/G. We thank G. Batholomae for the help with the XRF analysis, Necdet Özgül for discussions. P.Ö. Ustaömer, Antonio GarciaCasco, Dimitrios Kostopoulos and an anonymous reviewer provided constructive comments, which markedly improved the manuscript.

\section{References}

Allen, P., Condie, K.C. and Naryana, B.L., 1985. The geochemistry of prograde and retrograde charnokite-gneiss reactions in southern India. Geochem. Cosmochem. Acta, 49, 323-336.

Carrigan, C.W., Mukasa, S.B., Haydoutov, I. and Kolcheva, K., 2005. Age of Variscan magmatism from the Balkan sector of the orogen, central Bulgaria. Lithos, 82, 125-147.

Carrigan, C.W., Mukasa, S.B., Haydoutov, I. and Kolcheva, K., 2006. Neoproterozoic magmatism and Carboniferous high-grade metamorphism in the Sredna Gora Zone, Bulgaria: an extension of the Gondwana-derived Avalonia-Cadomian belt? Precambrian Res., 147, 404-416.

Cocks, L.R.M. and Torsvik, T.H., 2002.

Earth geography from 500 to 400 million years ago: a faunal and palaeomagnetic review. J. Geol. Soc. London, 159, 631-644.

Davis, P.B. and Whitney, D.L., 2006. Petrogenesis of lawsonite and epidote eclogite and blueschist, Sivrihisar Massif, Turkey. J. Metamorph. Geol., 24, 823-849.

Deloule, E., Alexandrov, P., Cheilletz, A., Laumonier, B. and Barbey, P., 2002. In situ $\mathrm{U}-\mathrm{Pb}$ zircon ages for Early Ordovician magmatism in the eastern Pyrenees, France: the Canigou orthogneisses. Int. J. Earth Sci., 91, 398-405.

Droop, G.R., Karakaya, M.C., Eren, Y. and Karakaya, N., 2005. Metamorphic evolution of blueschists of the Altınekin Complex, Konya area, south central Turkey. Geol. J., 40, 127-153.

Garfunkel, Z., 2004. Origin of the Eastern Mediterranean basin: a reevaluation. Tectonophysics, 391, 11-34.

Gürsü, S. and Göncüoğlu, M.C., 2006. Petrogenesis and tectonic setting of Cadomian felsic igneous rocks, Sandikl area of the western Taurides, Turkey. Int. J. Earth Sci., 95, 741-757.

Gutnic, M., Monod, O., Poisson, A. and Dumont, J.-F., 1979. Géologie des Taurides Occidentales (Turquie). Mém. Soc. Geol. France No., 137, 109 pp.
Hetzel, R. and Reischmann, T., 1996. Intrusion age of Pan-African augen gneisses in the southern Menderes Massif and the age of cooling after Alpine ductile extensional deformation. Geol. Mag., 133, 565-572.

Kober, B., 1986. Whole grain evaporation for ${ }^{207} \mathrm{~Pb} /{ }^{206} \mathrm{~Pb}$-age investigations on single zircons using double-filament thermal ion source. Contrib. Mineral. Petrol., 93, 482-490.

Kober, B., 1987. Single zircon evaporation combined with $\mathrm{Pb}+$ emitter bedding for ${ }^{207} \mathrm{~Pb} /{ }^{206} \mathrm{~Pb}$-age investigations using thermal ion mass spectrometry, and implications for zirconology. Contrib. Mineral. Petrol., 96, 63-71.

Kröner, A. and Şengör, A.M.C., 1990. Archean and Proterozoic ancestry in late Precambrian to early Paleozoic crustal elements of southern Turkey as revealed by single-zircon dating. Geology, 18, 1186-1190.

Kröner, A., Krüger, J. and Rashwan, A.A.A., 1994. Age and tectonic setting of granitoid gneisses in the Eastern Desert of Egypt and south-west Sinai. Geol. Rundsch., 83, 502-513.

Lisenbee, A., 1971. The Orhaneli ultramafic-gabbro thrust sheet and its surroundings. In: Geology and History of Turkey (A.S. Campbell, ed.), pp. 349360. Petroleum Exploration Society of Libya, Tripoli.

Loos, S. and Reischmann, T., 1999. The evolution of the southern Menderes Massif in SW Turkey as revealed by zircon dating. J. Geol. Soc. London, 156, 1021-1030.

Maniar, P.D. and Piccoli, P.M., 1989. Tectonic discrimination of granitoids. Geol. Soc. Am. Bull., 101, 635-643.

Mattauer, M., 2004. Orthogneisses in the deepest levels of the Variscan belt are not a Precambrian basement but Ordovician granites: tectonic consequences. $C R$. Geoscience, 336, 487-489.

Matte, P., 2001. The Variscan collage and orogeny (480-290 Ma) and the tectonic definition of the Armorican microplate: a review. Terra Nova, 13 , 122-128.

Monod, O., Kozlu, H., Ghienne, J.F., Dean, W.T., Günay, Y., Herisse, A.L., Paris, F. and Robardet, M., 2003. Late Ordovician glaciation in southern Turkey. Terra Nova, 15, 249-257.

Okay, A.I., 1984, Distribution and characteristics of the northwest Turkish blueschists. In: The Geological Evolution of the Eastern Mediterranean (J.E. Dixon and A.H.F. Robertson, eds). Geol. Soc., London, Spec. Publ., 17, 455-466.

Okay, A.I., 2002. Jadeite-chloritoid-glaucophane-lawsonite schists from northwest Turkey: unusually high $\mathrm{P} / \mathrm{T}$ ratios in continental crust. J. Metamorph. Geol., 20, 757-768.
Okay, A.I. and Kelley, S.P., 1994. Tectonic setting, petrology and geochronology of jadeite + glaucophane and chloritoid + glaucophane schists from northwest Turkey. J. Metamorph. Geol., 12, 455-466.

Okay, A.I. and Satır, M., 2006. Geochronology of Eocene plutonism and metamorphism in northwest Turkey: evidence for a possible magmatic arc. Geodin. Acta, 19, 251-266.

Okay, A.I. and Tüysüz, O., 1999. Tethyan sutures of northern Turkey. In: The Mediterranean Basins: Tertiary Extension within the Alpine Orogen (B. Durand, L. Jolivet, F. Horváth and M. Séranne, eds). Geol. Soc., London, Spec. Publ., 156, 475-515.

Okay, A.I., Satır, M., Tüysüz, O., Akyüz, S and Chen, F., 2001. The tectonics of the Strandja Massif: late-Variscan and midMesozoic deformation and metamorphism in the northern Aegean. Int. J. Earth Sci., 90, 217-233.

Okay, A.I., Satır, M. and Siebel, W., 2006. Pre-Alpide orogenic events in the Eastern Mediterranean region. In: European Lithosphere Dynamics (D.G. Gee and R.A. Stephenson, eds). Geol. Soc., London, Memoir, 32, 389-405.

Okay, A.I., Bozkurt, E., Satır, M., Yiğitbaş, E., Crowley, Q.G. and Shang, C.K., 2008. Defining the southern margin of Avalonia in the Pontides: geochronological data from the Late Proterozoic and Ordovician granitoids from NW Turkey. Tectonophysics doi: 10.1016/ j.tecto.2008.02.004.

Pearce, J.A., 1976. Statistical analysis of major element patterns in basalts. J. Petrol., 17, 15-43.

Prigmore, J.K., Butler, A.J. and Woodcock, N.H., 1997. Rifting during separation of eastern Avalonia from Gondwana; evidence from subsidence analysis. Geology, 25, 203-206.

von Raumer, J.F., Stampfli, G.M., Borel, G. and Bussy, F., 2002. Organization of pre-Variscan basement areas at the north-Gondwanan margin. Int. J. Earth Sci., 91, 35-52.

von Raumer, J.F., Stampfli, G.M. and Busy, F., 2003. Gondwana-derived microcontinents - the constituents of the Variscan and Alpine collisional orogens. Tectonophysics, 365, 7-22.

Roger, F., Respaut, J.-P., Brunel, M., Matte, P. and Paquette, J.-L., 2004. Première datation $\mathrm{U}-\mathrm{Pb}$ des orthogneiss oeillés de la zone axiale Montagne Noire (Sud du Massif central): nouveaux témoins du magmatisme ordovicien dans la chaîne varisque. CR. Geoscience, 336, 19-29.

Satir, M. and Friedrichsen, H., 1986. The origin and evolution of the Menderes Massif, W-Turkey: a rubidium/stron- 
tium and oxygen isotope study. Geol. Rundsch., 75, 703-714.

Schätz, M., Reischmann, T., Tait, J., Bachtadse, V., Bahlburg, H. and Martin, U., 2002. The Early Palaeozoic break-up of northern Gondwana, new palaeomagnetic and geochronological data from the Saxothuringian Basin, Germany. Int. J. Earth Sci., 91, 838-849.

Şengör, A.M.C. and Y1lmaz, Y., 1981. Tethyan evolution of Turkey, a plate tectonic approach. Tectonophysics, $\mathbf{7 5}$, 181-241.

Sherlock, S., Kelley, S.P., Inger, S., Harris, N. and Okay, A.I., 1999. ${ }^{40} \mathrm{Ar}-{ }^{39} \mathrm{Ar}$ and $\mathrm{Rb}-\mathrm{Sr}$ geochronology of high-pressure metamorphism and exhumation history of the Tavşanlı Zone, NW Turkey. Contrib. Mineral. Petrol., 137, 46-58.

Stampfli, G., 2000. Tethyan oceans. In: Tectonics and Magmatism in Turkey and the Surrounding Area (E. Bozkurt, J.A. Winchester and J.D.A. Piper, eds). Geol. Soc., London, Spec. Publ., 173, $1-24$.

Stampfli, G.M. and Borel, G.D., 2002. A plate tectonic model for the Paleozoic and Mesozoic constrained by dynamic plate boundaries and restored synthetic oceanic isochrons. Earth Planet. Sci.

Lett., 196, 17-33.

Veevers, J.J., 2004. Gondwanaland from 650-500 Ma assembly through $320 \mathrm{Ma}$ merger in Pangea to 185-100 Ma breakup: supercontinental tectonics via stratigraphy and radiometric dating. Earth Sci. Rev., 68, 1-132.

Wawrzenitz, N. and Krohe, A., 1998. Exhumation and doming of the Thasos metamorphic core complex (Rhodope, Greece); Structural and geochronological constraints. Tectonophysics, $\mathbf{2 8 5}$, 301-332.

Zanchi, A., Garzanti, E., Larghi, C., Angiolini, L. and Gaetani, M., 2003. The Variscan orogeny in Chios (Greece): Carboniferous accretion along a Palaeotethyan active margin. Terra Nova, 15, 213-223.

Received 25 May 2007; revised version accepted 30 April 2008 